\title{
Una experiencia de periodismo militante
}

\author{
José Abelardo Díaz Jaramillo
}

DOI: 10.5294/pacla.2020.23.4.7

Para citar esta reseña / to cite this review / para citar esta resenha

Díaz Jaramillo, J. A. (2020). Una experiencia de periodismo militante. Palabra Clave, 23(4), e2347. https://doi.org/10.5294/pacla.2020.23.4.7

Reseña de libro: Santos Calderón, Enrique (2019). Alternativa: lo mejor de la revista que marcó a una generación. Bogotá, Colombia: Debate. ISBN: 978-958-5446-88-5, 491.

A lo largo del siglo XX, las fuerzas de izquierda en Colombia, o para emplear un término de uso reciente, las expresiones alternativas, concibieron como necesidad contar con medios de comunicación escrita (periódicos, revistas) para difundir sus programas y puntos de vista. En la mayoría de los casos, se trató de experiencias de vida corta y alcances limitados (piénsese en la magnitud del tiraje o el número de lectores), gestadas en un contexto marcado por una cultura política proclive al bipartidismo tradicional que, por cierto, se expresaba por medio de cientos de publicaciones de carácter nacional, regional y local.

No obstante, es de reconocer una rica y compleja tradición de periodismo de izquierda que aún está por investigarse, en clave de descifrar su papel en la historia del periodismo en general en Colombia. Piénsese, a modo de ejemplo, en periódicos como Unirismo o Jornada, ligados al nombre de Jorge Eliécer Gaitán, o Frente Unido, el semanario que sirvió de plataforma comunicativa al sacerdote y político Camilo Torres Restrepo en 1965. Otros periódicos como Tierra, El Bolchevique, Diario Popular, Voz Proletaria y Voz

1 https://orcid.org/0000-0001-8279-2379. Corporación Universitaria del Meta, Colombia. jose.diaz@unimeta.edu.co 
del Pueblo (ligados a la historia del Partido Comunista), El Socialista (expresión del Partido Socialista de los Trabajadores) o Tribuna Roja (órgano del Movimiento Obrero Independiente y Revolucionario) son testimonio de aquella tradición a la que se ha aludido y de la que también hacen parte publicaciones que circularon desde principios del siglo XX.

El libro que se reseña es una compilación de artículos, reportajes, crónicas, entrevistas y caricaturas publicadas en Alternativa, quizá, la revista de izquierda más importante que haya sido editada en el campo del periodismo (para emplear la noción del sociólogo Pierre Bourdieu) colombiano en toda su historia, por razones que tienen que ver con el abordaje de temas que otros medios evadían, la concepción de periodismo que reivindicó (consignada en el lema "Atreverse a pensar es empezar a luchar"), las innovaciones que de la imagen y, sobre todo, haber atraído la atención de un amplio público (algo de por sí extraño) ligado a sectores de las clases medias (lo que se reflejó en el número de ventas por edición).

El libro es editado por Enrique Santos Calderón, miembro de una reconocida familia que ha estado unida al campo del poder político y al campo del periodismo (su tío abuelo fue propietario del diario más importante de Colombia durante décadas - El Tiempo - y presidente de la república entre 1938 y 1942; y su hermano Juan Manuel Santos fue presidente de la república en dos oportunidades). Enrique Santos fue uno de los fundadores de Alternativa y miembro del equipo editor entre 1974 y 1980. Esa doble condición le otorga méritos para hacer la compilación y la presentación, en la que recrea el origen, el papel y la importancia de la revista, las amenazas y agresiones de que fue objeto por parte de fuerzas oscuras, así como de las tensiones y rupturas entre los miembros del equipo editor.

Desde luego, se trata de la visión personal (la de Enrique Santos) frente a la cual otros miembros de Alternativa (los que aún continúan vivos) podrían disentir, como también lo pueden hacer quienes se interesen por la historia de la revista, algo que, por cierto, no ha ocurrido con suficiencia, lo cual puede ser un indicador del desconocimiento que existe de la historia del periodismo (que resulta ser, en parte, la historia de la política) en Colombia. 
La compilación de textos está organizada por secciones. En "Entrevistas", por ejemplo, aparecen célebres entrevistas que el equipo editor realizó a personajes del campo artístico en gran medida, y del campo político y del periodismo (Fernando Botero, Eduardo Galeano, Klim, Luis Carlos Galán, Julio Cortázar, Joan Manuel Serrat, Salvador Dalí, Regina 11, Felipe González y Alfonso López Michelsen). Otras secciones (editoriales, cartas, breves y humor, o crónicas y perfiles) permiten al lector de hoy identificar cuál fue el estilo de periodismo que cultivó Alternativa, lo que explicaría el grado de aceptación que alcanzó la publicación en la sociedad colombiana de la década de los setenta. A "La historia prohibida" el editor le abre un espacio reconociendo el éxito que tuvo esa sección que consistía en evocar (hacer memoria, se diría hoy) hechos históricos de gran impacto ocurridos en el país. En el libro, aparecen varias notas que refieren acontecimientos como el asesinato de Jorge Eliécer Gaitán, la irrupción de las guerrillas liberales en la década de los cincuenta y la caída de Alfonso López Pumarejo en 1945.

Se incluye, además, "Gabo alternativo", sección concebida como un reconocimiento a Gabriel García Márquez por sus notas periodísticas, pero, sobre todo, por su papel como impulsor de Alternativa. De hecho, Enrique Santos señala que, gracias a las ayudas económicas de García Márquez (Gabo era ya un escritor de talla internacional) logró la revista superar las recurrentes crisis financieras que la afligían. En la sección referida, se reúnen 18 textos del nacido en Aracataca, que sirven también para advertir su pensamiento político (el de la época, por supuesto) y comprender el porqué de la incomodidad del establiment con el escritor y, a la larga, la razón de su exilio.

El libro, que incluye imágenes en color de algunas carátulas de ediciones y caricaturas del celebre $E l$ señor agente, tiene, a nuestro juicio, un valor especial. Quienes reconocen la importancia de Alternativa y del periodismo militante que, con inteligencia y mucha valentía promovieron intelectuales, fotógrafos, artistas (hay que destacar los nombres de Daniel Samper Pizano, Orlando Fals Borda, Jorge Villegas Arango, Antonio Caballero, Jorge Mora, Diego Arango, Nirma Zárate, Víctor Daniel Bonilla, Carlos Duplat, Bernardo García y Cristina de la Torre, entre muchos otros), desde hace tiempo esperaban una edición de este tipo. 
Existen en bibliotecas públicas (en la Biblioteca Nacional y en la Hemeroteca de la Biblioteca Luis Ángel Arango, por ejemplo) colecciones de Alternativa que son de acceso libre. Sin embargo, la publicación de una compilación con parte del material periodístico de la revista, además de ser un reconocimiento explícito a ese proyecto comunicativo, significa que más ciudadanos podrán conocer la revista y dimensionar el tipo de periodismo que desde sus páginas se cultivó, y que, como lo reconoce el editor en la presentación, apuntaba a prestar un servicio al "proceso revolucionario colombiano" (p. 147) en los agitados años de la década de los setenta.

\section{Referencias}

Santos Calderón, E. (2019). Alternativa: lo mejor de la revista que marcó a una generación. Debate. 